\title{
Implementation of Dubido Based on Contextual in Improving Students Achievement on The Topic of Electrochemistry
}

\author{
Angeline Viska Ayu Rosalia \\ Magister of Chemistry Education \\ Unimed \\ Medan, Indonesia \\ Panjaitangie17@gmail.com
}

\author{
Saronom Silaban \\ Departement of Chemistry Education \\ Unimed \\ Medan, Indonesia \\ silabans@gmail.com \\ Zainuddin Muchtar \\ Department of Chemistry Education \\ Unimed \\ Medan, Indonesia \\ muchtar.zai@gmail.com
}

\begin{abstract}
The goal of this research was to know the gain of student achievement that taught by using dubido. The research has been done in Chemistry Educational Study Program in Unimed. The experimental class was given treatment with teaching by using dubido media based on contextual. The experimental class has fulfilled the requirement for normality and homogenity test. The mean of pretest results and posttest results were 36.615 and 82.769. The increase of posttest results indicated that learning by using dubido based on contextual can improve students achievement. The increase of students achievement signed by percent of gain with the value of gain percent was 74. The result of $t$ test was obtained from tcount is more than $t$ table (2.038 is more than 1.671) at a is 0.05 , it means that the implementation of dubido based on contextual was given positive effect to increase students achievement.
\end{abstract}

Keywords- Contextual, Dubido, Electrochemistry, Students Achievement

\section{INTRODUCTION}

Chemistry is one of difficult subject for students because it has difficult and abstract concepts[1]. This aim was to increase students' achievement in rate reaction topic. To improve students' achievement, we need an approach such as contextual teaching Contextual Teaching and Learning that is a proven concept that incorporates the most recent research in cognitive science $[2,3]$. This approach to teaching by recognizing as a reasonable and desirable strategy to enhance student learning in chemistry [4]. CTL approach has some teaching strategies, which include content as a critical in an active learning process that helps teachers realte subject matter to real world situation $[5,6]$. The curriculum greatly influences the quality of education in Indonesia. The curriculum is very necessary for the effectiveness of the education system. The curriculum is a plan prepared based on the objectives, content, methods, subject matter used as guidelines for learning activities to achieve the main objectives of education[7]. KKNI is the embodiment of quality and indetity of Indonesia related to national education and training system that is owned by Indonesia [8]. KKNI is an education curriculum of Indonesian that is a framework that leveling the competence qualification which integrate education, job training, and work experience in order to award the work competencies which in accordance with the people's working ability in various sectors [9]. Unimed is one of the universities in North Sumatra that has implemented its learning curriculum with KKNI [10]. Implementation of KKNI in Unimed aspire to produce students who are more accomplished, creative and good characters. KKNI has six tasks that students should submit it, the six tasks are Critical Book Review (CBR), Critical Journal Review (CJR), Mini Research (MR), Changing Idea (RI) and Project [11].

Based on the results of interviews with General Chemistry lecturers, it was known that there was no uniformity of learning media used by lecturers and students and the learning process was still teacher centered learning. The learning media and learning process of each lecturer were different so that it could lead to differences in abilities between students. Based on the results of learning in the General Chemistry course in recent years was still low. This was due to several factors including the lack of uniformity of the media used and learning was still teacher centered learning.

Based on the observations made there were some difficulties in the General Chemistry subject related to its characteristics, including (1) The concept of chemistry is abstract; (2) Chemistry does not merely solve problems but also describes chemical facts, chemical laws; (3) Chemical development is very fast [12].

There were several problems observed at the time of observation, namely the lack of uniformity of learning media and teaching materials which resulted in the learning process being teacher centered learning and low learning outcomes accompanied by low learning interest and student responses to learning. The low learning outcomes of chemistry was the impact of various problems that often arise in learning. Therefore, research was needed to find solutions to these 
problems such as the development of teaching media, approaches and learning models [13].

A lecturer must be able to find solutions to the obstacles encountered in the learning process. Lecturers must be able to facilitate the learning process of students in order to achieve the expected learning goals. Successful learning must be with good planning.

One of the good plans was the use of instructional media which has an important role in education, especially in improving the quality of student learning processes and outcomes. Learning media developed based on KKNI must follow the development of science and technology which has an important role in the advancement of education in accordance with the 4.0 industrial revolution and requires education to play an active role in the use of technology as a form of learning innovation so that the learning process is more effective and efficient without limitation of space and time $[14,15]$. The development of science and technology requires lecturers to be able to use technology so that they are able to create and develop teaching media that are suitable today [16].

In Indonesia, smartphones have been used throughout the country, both big cities and rural areas. Based on the UNICEF survey, it was recorded that internet users in Indonesia reached 30 million people or around $40 \%$ of the Indonesian population of whom $98 \%$ knew how to access the internet and $79.5 \%$ as internet users due to their affordable prices and various features. Smartphones have various types, iOs, Windows and Android [17].

Through the use of android-based media shows the ability of students to access information instantly without time and place restrictions and facilitate the process of cooperative learning [18].

The learning media to be developed is based on dubido in the form of a worksheet. Worksheets are supporting learning processes that contain introductory information, concepts, summaries and problem-solving instructions to enrich student understanding of the topic being studied and achieve learning outcomes $[19,20]$.

Dubido is a term of android mobile education that uses the gold appybuilder application. The author chose to use appybuilder because it can be operated easily and without coding. Dubido is a media worksheet that is developed containing material, experiments, and practice questions and is presented in the form of an APK. Dubido is expected to be an application that can be used by students and educators easily without limited space and time in training themselves to work on electrochemical problems so as to increase learning outcomes and interest.

Arifin reported that the development of an Android-based chemistry learning media can foster students' scientific literacy on redox and electrochemical reaction materials indicated an increase in the results of the 20.27 pretest science literacy competency test to a 74.16 post-test [21].

\section{METHOD}

This researrch used a quasi-experimental method with pretest-postest non equivalent group desing constisting of two classes aiming comparing the students achievement of general chemistry in the experimental I and experimental II class. Each class was given a pretest and posttest using the same test items related to students achievement in electrochemistry topic. the experimental I class was taught by using dubido based on contextual while the experimental II was taugh by using powerpoint.

The population in this research was all students of chemistry education study program in FMIPA Unimed and the sample was 50 students. There were 25 students in the experimental I and 25 in the experimental II class. The sampling techniques of both the experimental clas eployed simple random sampling. This technique was chosen because each sample had similar capability derived from the placement test anaylsis results. The research procedure can be shown in figure 1 .

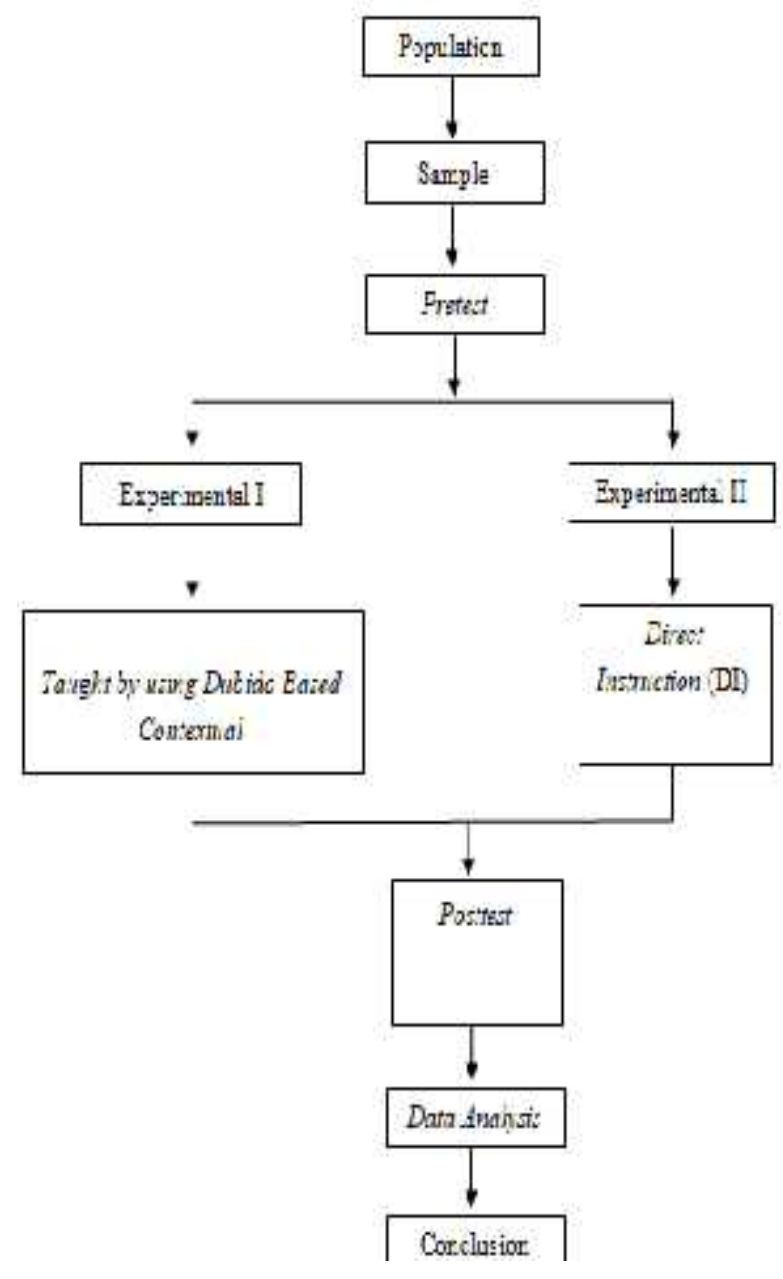

Figure 1. Research Procedure

The data collection instrument was in the form of test questions. The questions test were multiple choices related to indicators. The test items has chosen from National Examination.

The data were analyzed descriptively based on the average score, then an inferential statistic with t-test was carried out. Before the t-test, a preerquisite test was done, a normality and homogenity test. The test result on both pretest and the posttest for each sample from the the population were normally and 
homogeneously distributed ( $\mathrm{p}>0.05)$. therefore, it could be proceed to the parametric analysis (hypothesis test) through ttest.

\section{RESULT AND DISCUSSION}

Before testing the hypotheses, all the data must be normally distributed and relatively homogeneous in order to make the data are statistically allowed to be process. The data of this research had been processed by normality and homogenity test by using SPSS 21. The result of test showed the statistical evidances to get closer to the expected conclusion.

\section{A. Normality Test}

The result data was $\mathrm{N}$ gain data. Data was tested by Kolmogrov Smirnov test that data was normal if the sig.> $\alpha$ $(0.05)$. the result of normality test was shown in table I.

Table I. Normality Test on Electrochemistry Topic.

\begin{tabular}{|c|c|c|c|}
\hline \multirow{2}{*}{ Class } & \multicolumn{2}{|c|}{$\begin{array}{c}\text { Kolmogrov- } \\
\text { Smirnov }\end{array}$} & \multirow{2}{*}{ Distribution } \\
\cline { 2 - 3 } & A & Sig. & \\
\hline Experimental I & 0.05 & 0.200 & Normal \\
\hline Experimental II & 0.05 & 0.200 & Normal \\
\hline
\end{tabular}

Based on the table I, all the research data have the significant value which is higher than 0.05 , so that it can be concluded all the data are normally distributed. By this value, it means that all the data can be statistically used to reveal the hypotheses.

\section{B. Homogenity Test}

The homogenity test used in this research was Levene's Test for Equality of Variances in which the data was homogenous if the sig. .> $\alpha(0.05)$. the result of normality test was shown in table II.

Table II. Homogenity Test on Electrochemistry Topic.

\begin{tabular}{|c|c|c|c|}
\hline Data & A & Sig. & Status \\
\hline Experimental I & 0.05 & 0.815 & Homogen \\
\hline Experimental II & 0.05 & 0.638 & Homogen \\
\hline
\end{tabular}

Based on the table II, all the research data have the significant value which is higher than 0.05 , so that it can be concluded all the data are homogeneouus. By this value, it means that all data can be statisically used to reveal the hypotheses.

\section{Data of Research Result}

Before conducting teaching treatment in both experimental class, this research was started by doing pretest. The pretest scores in both classes were collected as the first data. It was then followed by doing teaching treatment and posttest was given in both classes to measure student's achievement in the last session. Student's achievement is defined as the difference of pretesst average scores and posttest average scores. The higher difference can be seen from the higher achievement gained by student.

The student's achievement gain is presented in the following table III.
Table III. Student's Achievement

\begin{tabular}{|l|l|l|l|l|l|l|}
\hline Class & \multicolumn{2}{|l|}{ Pretest } & \multicolumn{2}{|l|}{ Postest } & \multicolumn{2}{l|}{ N-gain } \\
\cline { 2 - 7 } & Mean & $\begin{array}{l}\text { Std. } \\
\text { Error } \\
\text { Mean }\end{array}$ & Mean & $\begin{array}{l}\text { Std. } \\
\text { Error } \\
\text { Mean }\end{array}$ & Mean & $\begin{array}{l}\text { Std. } \\
\text { Error } \\
\text { Mean }\end{array}$ \\
\hline E-I & 36.615 & 10.350 & 82.769 & 8.964 & 0.741 & 0.114 \\
\hline E-II & 49.538 & 10.497 & 84.154 & 5.364 & 0.672 & 0.127 \\
\hline
\end{tabular}

Based on the table III, the average of pretest in experimental II is $49.538 \pm 10.497$ and in experimental $\mathrm{I}$ is $36.615 \pm 10.350$. Having gotten the teaching treatment, the posttest in experimental II is 84.154 \pm 5.364 and in experimental I is $82.769 \pm 8.964$. from this data, we known that the percent of gain in experimental II is $67.2 \%$ and experimental I is $74.1 \%$. by this value, it can be concluded that the increasing of students' achievement in experimental $I$ is higher than experimental II can be shown in figure 2 .

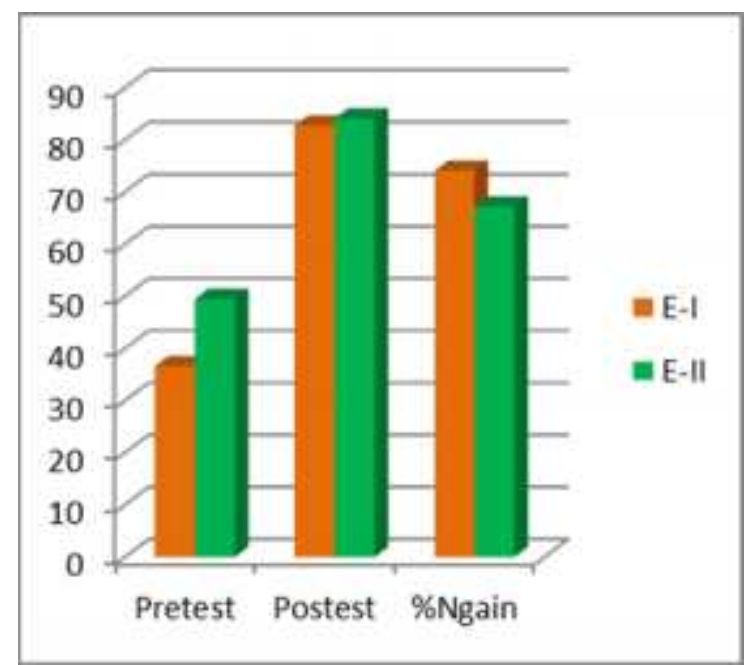

Figure 2. The Students’ Achievement

The success of this research had been tested and giving positive result. The effectiveness of implementation dubido based contextual as the chosen media on the teaching of electrochemistry in improving students' achievement was studied by comparing the overall result to the direct instruction. By comparing those values, there is significant difference between students' achievement in experimental I and experimental II where the experimental I class is statistically better than experimental II. Thus, dubido based contextual in teaching electrochemistry was statistically proven to be able to improve students' achievement was statiscally better than direct instruction with powerpoint.

\section{CONCLUSION}

The result of dubido based contextual in teaching electrochemistry was given improvement to students' achievement. This media can be used for students because this media is effective and efficient, students' can used it everytime. 


\section{ACKNOWLEDGMENT}

The author would be like to acknowledge Dr. Zainuddin Muchtar, M.Si and Dr. Saronom Silaban for supervising this research.

\section{REFERENCES}

[1] Fadillah, A., Dewi, N. P. L. C., Ridho, D., Majid, A. N., \& Prastiwi, M. N. B. (2017). The effect of application of contextual teaching and learning (CTL) model-based on lesson study with mind mapping media to assess student learning outcomes on chemistry on colloid systems. In International Journal of Science and Applied Science: Conference Series (Vol. 1, No. 2, pp. 101-108).

[2] Davtyan, R. (2014, April). Contextual learning. In ASEE 2014 Zone I Conference (pp. 3-5).

[3] Thomas, J.W. (2000). A Review of Research On Project Based Learning.

[4] Klassen, S. (2006). A theoretical framework for contextual science teaching. Interchange, 37(1-2), 31-62.

[5] Satriani, I., Emilia, E., \& Gunawan, H. (2012). Contextual teaching and learning approach to teaching writing. Indonesian Journal of Applied Linguistics, 2(1), 10-22.

[6] Sears, S. J. (2003). Introduction to contextual teaching and learning. Phi Delta Kappa Educational Foundation.

[7] Anggraini, A. (2014). The Implementation of Cooperative Learning STAD Type with Multimedia Based on Computer to Foster Teamwork and Increase Students' Achievement in Redox Reaction Topic. Unimed, FMIPA. Medan: Unimed.

[8] Latip, A. E. (2015). Curriculum Readiness and Program Evaluation In Implementing Indonesian National Qualifications Framework Curriculum (KKNI). Journal of Education in Muslim Society 2(2): 191203

[9] Dokumen 0012015 Kerangka Kualifikasi Nasional Indonesia (KKNI) Kementrian Ristek, Teknologi, dan Pendidikan Tinggi
[10] Darari, M. B., \& Simanjuntak, E. (2019, March). Relationship 6 task KKNI for student's scientific publications. In Journal of Physics: Conference Series (Vol. 1188, No. 1, p. 012045). IOP Publishing.

[11] Tiur M S, Suci F 2017 Development of Teaching Book Based on KKNI International Journal of science and Research (IJSR) 7(5): 298

[12] Yamtinah, S., Budiyono, B. (2015). Pengembangan instrumen diagnosis kesulitan belajar pada pembelajaran kimia di SMA. Jurnal Penelitian dan Evaluasi Pendidikan, 19(1), 69-81.

[13] Olic, S., \& Adamov, J. (2018). The Relationship Between Learning Styles and Students Chemistry Achievement. Macedonian Journal of Chemistry and Chemical Engineering, 37(1), 70-88.

[14] Ahmar, A. S., \& Rahman, A. (2017). Development of Teaching Materia Using an Android. Global Journal Of Engineering Education, 19(1), 72 76.

[15] Amelia, R. D. (2016). Pengembangan Media Pembelajaran Education Mobile Berbasis Android Pada Mata Pelajaran IPA Fisika Kelas VIII di MTs Al Asror Patemon Kecamatan Gunungpati Kota Semarang. Semarang: Unnes Press

[16] Jaslin, I., \& Lubis, I. (2015). Pengembangan Media Pembelajaran Kimia Berbasis Android Untuk Meningkatkan Motivasi Belajar dan Prestasi Kognitif Peserta Didik SMA. Jurnal Inovasi pendidikan IPA, 1(2), 191201

[17] Saharudin. (2011). Perkembangan Teknologi Komunikasi. Yogyakarta: Pustaka Akademika

[18] Rossing, J. P., Miller, W., Cecil, A. K., \& Stamper, S. E. (2012) iLearning: The Future of Higher Education? Student's Perceptions on Learning Mobile Tablets. Journal of Scholarship of Teaching and Learning, 12(2), 1-26.

[19] Astra, I. M., Nasbey, H., \& Muarramah, N. D. (2015). Development of Student Worksheet By Using Discovery Learning Approach For Senior High School Student. Journal of Education in Muslim Society, 2(1), 9196

[20] Demoin, D. W., \& Jurisson, S. S. (n.d.). Chemical Kinetics Laboratory Discussion Worksheet.

[21] Harianto, A., Suryati, \& Khery, Y. (2018). Pengembangan Media Pembelajaran Kimia Berbasis Android Untuk Penumbuhan Literasi Sains Siswa Pada Materi Reaksi Redoks dan Elektrokimia. Jurnal Ilmiah Pendidikan Kimia "Hydrogen", 5(2), 35-45. 